ICEEPSY 2021

$12^{\text {th }}$ International Conference on Education \& Educational Psychology

\title{
THE USAGE OF THE GRAPHIC NOVEL IN TEACHING GERMAN AS A FOREIGN LANGUAGE
}

\author{
Nadezda Heinrichova (a)* \\ *Corresponding author \\ (a) University of Hradec Kralove, Faculty of Education, Rokitanskeho 62, 50003 Hradec Kralove, Czech Republic, \\ nadezda.heinrichova@uhk.cz
}

\begin{abstract}
Graphic novels are some of the most popular books of the $21^{\text {st }}$ century set to be read by pupils and students. This paper is a contribution to the usage of a graphic novel Belonging: A German Reckons with History and Home (Heimat. Ein deutsches Familienalbum, 2018) by Nora Krug by university students majoring in German as foreign language at the Education Faculty of University Hradec Kralove in the Czech Republic. Typical feature is work with documentary material in this partly written and drawn family novel which conveniently enables its use in German FL lessons. The aim of this paper is, firstly, to explain the suitability of documentary material to practise students' existing German skills and to understand German history of the $20^{\text {th }}$ century and secondly, the development of visual literacy, because being able to interpret pictures (both static and moving) is important, especially in the age of the internet. Additionally, students had to generate arguments to identify themselves with one of the chosen characters and to compare their current situation with the life in West Germany and in the Eastern Block. All these activities couuld be later used by the students when teaching their own pupils.
\end{abstract}

2672-8141 (C) 2021 Published by European Publisher.

Keywords: Graphic novel, post-2000 German prose, Nora Krug, FLT, homeland 


\section{Introduction}

Nowadays, most pupils and students do not see any reason to spend their free time reading novels or short stories. The quality of reading skills has changed completely since young people prefer to read on screen rather than read some book. Reading has become too difficult for them because they have to be able to imagine what is happening. Graphic novels can provide teaching and learning opportunities for readers, educators, and researchers (Griffith, 2010). Therefore, it is recommended to integrate graphic novels in teaching (Elsner, 2013; Norton, 2003) a foreign language. A good quality graphic novel offers the immediacy of the prose reading experience, with the pictures and the words working simultaneously, making a graphic novel not only something one reads but something one sees as well, like reading and watching a movie at the same time (Gallo \& Weiner, 2004, p. 115). The best known example of this is English comic book Maus (1980; a special Pulitzer Prize in 1992) by Art Spiegelman, which was translated into many languages. According to McTaggart (2008), Art Spiegelman's winning the special Pulitzer Prize in 1992 immediately validated not only Maus, but the entire genre of graphic novels. Using suitable graphic novel in FLT is an ideal way to help students majoring in teaching German to find pleasure in reading a book and to teach history of German speaking countries at the same time. The paper builds on and expands on previous articles on the use of $21^{\text {st }}$ century German FLT literature, as all student activities during the seminar help them later as would-be teachers to be able to explain the German history, culture and literature to their pupils (Heinrichova, 2020).

We can find some graphic novels, which are already used and recommended in Germany at secondary and grammar school: Die Sache mit Sorge (2014) by Isabel Kreitz reflects the story of Stalin's spy, Richard Sorge, who works in the German embassy in Tokyo. Ingrid Sabisch and Heiner Lünstedt expose the life story of the courageous Sophie Scholl in the graphic novel of the same name Sophie Scholl (2015).

This paper deals with the graphic novel Belonging: A German Reckons with History and Home (2018) by Nora Krug (*1977 Karlsruhe, West Germany). This visual memoir (German edition title Heimat) was chosen as the best book of the year by the New York Times, The Guardian and etc. This graphic novel was the winner of the 2019 National Book Critics Circle Award (Autobiography Category), of the Lynd Ward Graphic Novel Prize (winner), the Art Directors Club (Gold Cube and Overall Discipline Winner), and the British Book Design and Production Award (graphic novel winner) among others. The German title Heimat won also many literary prizes (Schubart-Literaturpreis - 2019, Evangelischer Buchpreis - 2019) and awards and has been nominated many times (shortlist: German Youth Literature Prize of the 2019 and 2020). Krug's book exposes the family history with the help of documentary material. The author's trip to the past shows what it means for her generation to be a German feeling guilt for the events of $20^{\text {th }}$ century. Generation feeling the guilt both in Germany, her native country, as well as abroad. Ordinary people describe their lives in Germany in the times of National Socialism, later, in west zones after 1945 and also in West Germany after 1949. Her graphic novel describes the approach to the history based on official attitude of the state doctrine and on people's personal experience too.

Current didactics of FL is based on communicative method in the ability to communicate. Learning English as the first FL, students in the Czech Republic usually know some English written comic book. 
German, Russian or Spanish are the second FL in the Czech Republic. German is for pupils and students in the Czech Republic a little bit more difficult than English. We can also use students' previous knowledge of English when using the graphic novel Belonging (2018) by Nora Krug. The students majoring in teaching German often study English as their first FL. For that reason, they as future "[...] language teachers can conveniently motivate their pupils to use their previously acquired language knowledge and skills to make the whole process of learning another language more effective" (Ondrakova \& Tauchmanova 2020, p. 174). Perception of foreign languages is a very complicated phenomenon, which has a sensory character and can act with only two senses presented - hearing and vision (Besedova \& Voriskova, 2020), what seems to be another reason and at the same time a benefit of working with graphic novel in FLT.

\section{Problem Statement}

Since students grow mostly up with some screen (smart phone, a TV, graphic software, electronic or video games etc.) they often need pictures to visualise and to imagine the content of individual messages. The graphic novel satisfies this need (McTaggart, 2008). One of the most significant reasons for using graphic novel is also the development of visual literacy (Crawford 2004; Goodson et al., 2002). If the students and pupils are not capable of understanding and interpreting an image's message, they could become a victim of false information or bullying. Therefore, it is recommended to use graphic novel in FLT. Its using helps, in our case, the teacher to develop and to train the students' language skills, and also, to increase historical and cultural awareness by students majoring teaching German as FL.

\section{Research Questions}

There are two basic questions to be answered in this paper that are closely connected: Q1: Do students have knowledge about the history in Germany in the times of National Socialism, later, in west zones after 1945 and also in West Germany after 1949?

Q2: Does using of the graphic novel - by Nora Krug Belonging - motivate students' interest in other graphic novels which leads to voluntary search for other information about the history and the life in Germany in $20^{\text {th }}$ century?

\section{Purpose of the Study}

The purpose of this study is to explain to the university students majoring German as a FL during an elective literary course on the example why a how we can use the graphic novel Belonging by Nora Krug in FLT. As this graphic novel reflects the family history of Nora Krug and because it is both impressive and powerful, it is possible, as the first aim, to make students look for arguments to identify themselves with one of the three previously chosen characters. Secondly, to practise students' existing German skills when reading this book (which contains literary texts and documentary material) as a way to understand life in Germany in the times of National Socialism, later, in west zones after 1945 and also in West Germany after 1949 as an important part of history of the $20^{\text {th }}$ century. Last, but not least to develop visual literacy and to understand an image's / picture's message. The students should be able to understand and, above all, to interpret the meaning of the pictures and documentary material from the era of National Socialism. 


\section{Research Methods}

The literary seminar devoted to Interpretation of German literature of the $21^{\text {th }}$ century about everyday life and important historical events in the $20^{\text {th }}$ century was attended by 12 students ( 9 female and 3 male) majoring German as a FL. This literary seminar took place virtually in the Teams environment in winter term 2020 and it lasted 13 weeks.

The following books The Blind Side (Die Mittagsfrau, 2007) by Julia Franck and This House is Mine (Altes Land, 2002; filmed 2019) by Dörte Hansen were treated in the further part of this course. At the same time, three contemporary women writers - Nora Krug (*1977), Julia Franck (*1970), Dörte Hansen $(* 1964)$ - were introduced in the course. The main topic in these novels is homeland and what it means to have to leave the native country.

The students were expected to read all these three books. They were also given the opportunity to watch the film This House is Mine (2019) as a replacement for the novel of the same title by Dörte Hansen.

In order to motivate the students, they were encouraged to find associations with the key word Heimat (homeland, motherland, fatherland, native land, native country) to activate their previous knowledge. After that, we used these following research tools (a mind map, a minute paper, wbo collaborative whiteboard, padlet) to collect data to understand the extent of students' previous knowledge of historical milestones of the $20^{\text {th }}$ century $(1918,1933,1939,1945,1961,1989,1990)$, of Nora Krug and of the graphic novel \& comics as literary genre. The students could give same concrete (positive or negative) examples of these terms.

Although the course took place virtually, the structure of the course was the same as in the face-toface class. Similar tools were also used for presentation, revising and checking students' knowledge (power point, Kahoot).

In the first course lesson the subject, the program and the objective of the seminar were introduced and the tasks for the next few hours were distributed. For the next lessons, three students were always supposed to prepare a presentation about Nora Krug's life and work, three other students presented the four dimensions of the homeland (defined by Gerhard Handschuh, 1990), three others focused on the documentary material in this graphic novel and to get an overview they presented all types of documentary material which Nora Krug used in so-called book "From The Scrapbook Of A Memory Archivist", and the remaining three colleagues treated graphic novel as one of the literary forms. They also explained the differences between a comic book and a graphic novel, because not all comics are automatically graphic novels. The students took notes during the presentations so that they could take part in further activities that followed immediately afterwards. The aim of these activities was to revise students' knowledge and to broaden it.

All twelve students were randomly divided into four groups in Teams for speaking activities and I checked their group work in these four virtually set rooms.

First, in each group, the characteristics of the tree main characters (1. Nora Krug; 2. her uncle, FranzKarl Krug, 1926-1944; 3. her maternal grandfather, Willi Rock, 1902-1988) and the social-historical background were prepared. The students identified themselves with one of these three main characters and explained the decisions of this character. This was followed by the inner monologue, comments and 
dialogue too. After the role play, the students still in the four groups inspired by the Krug's "Notebook on a homesick émigreé" prepared their own list of 10 items they associate with Heimat. In other words, which everyday objects the students associate with the term homeland (Heimat) and then they compared it with this list in Krug's book. These items from students' "notebook" were presented to other three groups.

Besides these speaking activities, the students practised also their existing writing skills. Each student had a writing task as homework. This set task was based on the work with the chapter titles. The students chose 3-5 chapter-titles from 15 chapters and wrote an essay from Nora Krug's perspective, e.g. about her class trip to a concentration camp; how her classmates felt after the visit to the extermination site Birkenau in 1994; why she felt the need to know, where she comes from; why she felt more German after 12 years of living in America than ever before; why she looked for books about her hometown at the New York Public Library; why she wanted to learn about its wartime history; what and how her feelings changed after finding information about the lives of her ancestors etc. The students compared this perspective in their essay with their current situation and with their own lives. This topic was completed by students' discussion about the post war situation in Eastern Block and in West Germany, where and why felt people guilty.

\subsection{Information to the author and book (title, structure and content)}

Nora Krug is a German-American author and illustrator. These days, Krug's visual narratives and drawings have appeared in many newspapers such as the American daily newspaper The New York Times, in the British daily newspaper The Guardian, the French monthly newspaper Le Monde diplomatique, in many anthologies and chronicle books. She is also a recipient of fellowships from Fulbright, the John Simon Guggenheim Memorial Foundation, the Pollock-Krasner Foundation, the Maurice Sendak Foundation, and others. Krug's illustrations have been recognized with many medals.

While studying in New York, Nora Krug said she began to feel ashamed of her home country because as soon as she answered someone who asked her where she was from, the association with the Nazi period arose. You are constantly confronted with it (Oltermann, 2018). Nora Krug knew little about her own family's involvement in the war, although all four grandparents lived through the war, they never spoke at home of it. Krug felt a strong need both for the history of her country, as well as for processing the history of her family and her home in a new way (Apruzzese, 2019).

She married into a Jewish family whose ancestors had to leave Germany before the Second World War. These were the reasons why she began to research and record the lives of their ancestors during World War II thoroughly. Nowadays, Nora Krug lives with her husband and daughter in Brooklyn and is an Associate Professor of Illustration at the Parsons School of Design in New York City.

However, the first impulse for creating the book was a visit to a military cemetery in northern Italy, located between Florence and Bologna. She and her parents discovered it by accident during their summer holiday (Chapter 3 of the novel Belonging). Nora Krug, then twelve, watched her father searching the alphabetical list of 30,000 fallen German soldiers for the name of his brother, whom he had not experienced, yet, after whom he was given the same name Franz-Karl Krug (Piepgras, 2018). Nora Krug's father was not born until two years after his brother's death, in 1946. 
The above-mentioned circumstances forced the author to start searching family history, to find out more about the possible participation of her ancestors in the events of the Nazi era, and to map the essence of Germanism for herself. Krug explains this need by the words of Hanna Arendt: He who lives abroad is far more confronted with being German than he who has remained at home, because everyone is guilty at home (Piepgras, 2018). Krug managed to find various traces in the archives and documentary materials of her own family, which she set out on. She heard stories from relatives and complete strangers, which she then captured in her graphic novel in various graphic ways, words and drawings. In terms of form, Nora Krug was inspired by Japanese comics and essay documentaries.

The book is partly handwritten and partly hand-drawn comic supplemented by a number of photographs from her own family, as well as pictorial or written material that Krug obtained during his careful research work. She drew on letters, archival material, flea market finds, and photographs to attempt to understand what it means to belong. Secondary and primary sources are listed at the end of the book, but at the same time we can find a note that not all materials could be classified more specifically.

Formally, the story is divided into fifteen chapters of various lengths and a final epilogue. The chapter titles are as follows: 1. "Early Dawning", 2. "Forgotten Songs", 3. "Poisonous Mushrooms", 4. “Keeping Time”, 5. "Unhealed Wounds", 6. "Looking Inside”, 7. "Fathomless Forests", 9. "Melting Ice", 10. “Looking For Traces”, 11. "Soft Return”, 12. "Following the Flock”, 13. "Peeling Wallpaper”, 14. "Blinding Whiteness", 15. "Shaking Hands". The book begins with a short introductory text, reflecting the already mentioned feelings of shame that the author experiences during her stay in New York during her studies. Pages are not numbered. The reader has the opportunity to look into the feelings of a teenage author through a foreign language, to co-attend a mandatory visit to a concentration camp and, surprisingly, to learn about the forcible occupation of land and orchards for the need of US military (Chapter 13). Although Krug says she has moved away from her home and her stay in America has changed her thinking, behaviour and language, she still lacks walks through the German forest and German bread (Harmsen, 2012). For this reason, she lists them as two of the eight associations in the following "notebook of a homesick émigré".

The novel Heimat meets the requirements of the framework composition, which consists of eight German things/records in the so-called "From the notebook of a homesick émigré", with which Nora Krug associates her home. Home, with its traditional attributes is [often ...] the origin and anchor point in human existence at the material [...] level (Mlsova, 2003). Krug states everyday objects that represent a feeling of security, safety and warmth of home. These things are named in German and explained in English. At the very beginning of the book, we find the first of them: № 1 "Hansaplast" (a brand of bandage developed in 1922). This is followed by an entry dedicated to the German forest (№ 2 "der Wald") at the end of the first chapter. The third chapter called "Poisonous Mushrooms" with which the following entries also correspond homework assignment from January 20, 1939 (The Jew, a Poisonous Mushroom), or the photograph of the Nora Krug's mother, dressed in a costume of a poisonous mushroom from 1953. At the same time, there is a third entry from this notebook, associating home, collecting mushrooms (№ 3 “das Pilzesammeln"). In the fourth chapter, the fourth notation appears, the binder, named after its inventor, Leitz, developed in 1896 (№ 4 “der Leitz-Aktenbinder"). The fifth record in chapter 6 is devoted to the thermophore, the hot water bottle (№ 5 "die Wärmflasche"). In Chapter 12, we come across two records: (№ 6 “das Brot”) bread and special soap made of ox gallbladder (№ 7 “die Gallseife”). The last eighth 
entry, the first synthetic (bone-glue-free) resin adhesive in the world, in 1932 (№ 8 "der Uhu"), closes the whole book.

In terms of genre, the author works with specific means of expression of comics. Within the subgenre, you can also use the term historical graphic novel or documentary comic. This is a personal story of the author and her family, which is why Nora Krug's self-concept, her experience is strongly reflected here. The interconnection of the text and the image allows her to jump in space and time. The pictorial material (photographs, drawings, illustrations) is supplemented by text records, the already mentioned memories or experiences of the author and other characters, newspaper articles, diary entries, entries in school notebooks from the period of National Socialism and more. Although this form of arrangement offers the reader sketchy and non-linear information, reminiscent of a kaleidoscope of events, after reading it, the reader will appreciate the ingenious connection of this mosaic-like story.

In terms of content, this graphic novel brings a picture of the time, a political system that fundamentally influenced the behaviour of individuals during the National Socialist period and subsequently the post-war period in the western zones. At that time, the German population was divided into five groups as part of the so-called denazification: Major Offender, Offender, Lesser Offender, Follower, and Exonerated Person. We learn from the novel that it was a great fortune to get into the penultimate category called Mitläufer (Follower; see Chapter 12), that is, the one who joined the regime without getting involved. During the proceedings before the Arbitration Court (Spruchkammerverfahren), over fifty percent of the population ended up in this category, and it was not possible to determine clearly whether they were guilty or innocent or to what extent they are guilty (Piepgras, 2018).

In this context, Nora Krug's desire remains to find out the real truth about the two characters, her maternal grandfather (Willi Rock, 1902-1988), a teacher at a driving school which he bought or took over after the deportation of a Jewish neighbour Robert Wagner (Chapter 12). Although Willi Rock was considered a Democrat in the family, Krug finds out from US military documents, and especially from his 300-question questionnaire, which he fills out as part of the denazification, that Willi Rock joined the NSDAP as early as 1933 (Chapter 12). The second character is the aforementioned uncle, father's brother, SS soldier, Franz-Karl (1926-1944), whose footsteps the author follows. The fates of these two characters line the whole story of the novel. In confrontation with them, Krug documents not only her childhood and adolescence, but also the life stories of other family members from previous generations. The orientation between the individual members of both families is facilitated by the reader with two illustrated pedigrees. In the case of the mother's family, there are twelve characters, starting with her great-grandfather, his two wives, through his grandfather (Willi Rock), to Nora Krug's mother (Rita, born in 1946, by profession teacher). The father's family is also represented by his great-grandfather and his wife, grandparents, through his late uncle (Franz-Karl, 1926-1944) to Nora Krug's father (professor Franz-Karl Krug, born 1946). The key question for the author is what the war does to men, how this experience affects the consciousness of future generations.

Through documentary material, Krug reflects various concepts of the term 'homeland' as a place that fundamentally influences us, where our identity is co-created, where experience is passed on from generation to generation. She compares these feelings and experiences with her new home in America and with her new identity. In 2017, Nora Krug acquired American citizenship, and at the same time retains 
German citizenship (Piepgras, 2018). Krug spends her summer holidays regularly in Germany, perceiving great differences in identification with her homeland, with the importance of home for Germans and Americans. Unlike America, Germany is a welfare state that is expected to take care of its citizens. That is why no one here asks, as in America, what I can do for my country, my home and how I can help others (Piepgras, 2018).

\section{Findings}

Research question 1: Do students have knowledge about the history in Germany in the times of National Socialism, later, in west zones after 1945 and also in West Germany after 1949?

Spontaneous associations with the term 'homeland' showed students' interest in this topic at the beginning of this literary course. They mentioned the following terms: parents, family, house, birth country, native language, nature, Czech Republic, the feeling of security, God, etc. In case of these associations, there was no surprise. After that, the students should have recalled five important historical events, milestones of $20^{\text {th }}$ century. Since they were final-year students who had studied the history and cultural studies of German-speaking countries, they were able to come up with the right year and event with some examples: 1914-1918 (first World War; The dissolution of Austria-Hungary), 1918 (the origin of Czechoslovakia; T.G. Masaryk, first president), 1933-1949 (period of national socialism; specific names of representatives of the Nazi elite), 1939-1945 (World War II; names of generals, famous battles, Stalingrad, expulsion of the Sudeten German population), 1949 (the emergence of two German states; air bridge in Berlin, interesting facts from life in East Germany and West Germany), 1961 (construction of the Berlin Wall), 1989 (fall of the Berlin wall), 1990 (reunification of Germany). But they were unable to say anything about Nora Krug as they had not heard this name yet. Although all students have to complete the compulsory Lecture Introduction to Literary Studies in the first semester, very few recalled the characteristics of graphic novel and comics as literary genre.

At the beginning of this course, the students had knowledge about the history in Germany in the times of National Socialism, later, in west zones after 1945 and also in West Germany after 1949. They were also able to give many specific examples and some connections from Czechoslovak history.

To answer the research question 2: Does using of the graphic novel - by Nora Krug Belonging motivate students' interest in other graphic novels which leads to voluntary search for other information about the history and the life in Germany in $20^{\text {th }}$ century? Then the students were asked: What other graphic novels do you know? Do you like them and why?

More students were able to give examples of comics or graphic novels they read. The first mentioned comics were: Tom and Jerry, Little Mole, Lucky Luck, Garfield, Iron Man etc. They also presented the following graphic novels: Maus, Star Trek, Conan, Dune, Dragon Age, and also Mangas. All students confirmed that they like these and read them when they were younger.

After the presentations, group work, role play based on the three main characters in this novel, followed their monologues and dialogues in which they practised different points of view of the three characters and trained existing German language skills as well. They identified themselves with the characters and searched for arguments for the behaviour of these persons. During group work, they found 
some everyday objects and presented and explained them to the other students in their own 'notebook on a homesick emigre'.

The students got most engaged in work with documentary material which had been introduced in one of the presentations. They were surprised at the variety of objects that can be bought at a flea market. They were shocked by the photographs of smiling German soldiers (from Nazi period) holding and caressing some pet, such as puppy, kids, Guinea pig or horse. The students got stunned as they normally do not expect any humane gentle feelings from a person wearing a military uniform of Nazi period. The students were also taken by surprise when working with pupils' school notebooks from Nazi period that show clear manipulation and instrumentalization of the children who had written those homework tasks. The same shock was realizing that more than $50 \%$ of German population wished to belong to the category of 'Follower'. They compared this position with the period of communist totality in Eastern Block, they tried to understand the meaning of passive collaboration and why silence and not stepping out of majority is dangerous.

The students also wrote an essay based on the $3-5$ chapter-titles, which they chose. They compared Nora Krug's perspective with their own situation in the post war situation in the Czech Republic, Eastern Block and in West Germany. It is worth noticing that ten from twelve students chose the title of the last chapter "Handshaking" representing reconciliation and forgiveness for the past of their ancestors.

This graphic novel about Nora Krug's family history motivated students who voluntarily searched for more examples. Although the students were not originally interested in this historical period, thanks to graphic form they discovered Czech versions of graphic novels: 1984 (2021; illustrated by Matyáš Namai), Anthropoid (2017) by Zdeněk Ležák and Michal Kocián, Alois Nebel by Jaroslav Rudiš, Zátopek (2020) by Jan Novák etc., and some of them started to find WWII literature fascinating.

\section{Conclusions}

It can be concluded that the graphic novel Belonging: A German Reckons with History and Home by Nora Krug is a strong family story which has a significant pedagogical potential in FLT. This visual memoir can already be described as a bestseller that examines German identity and at the same time deals with the issue of German guilt and various concepts of homeland. Homeland is a term that refers to a sense of belonging to a country of birth, which has also taken on a different meaning as a result of Nazi propaganda. This controversial topic is very interesting and motivating for students majoring in teaching German as a foreign language. The book presents and offers an interesting way to learn and to understand history of the $20^{\text {th }}$ century. The work with various documentary, authentic material develops students' visual literacy. During presentation and other activities, the students started to compare their image of homeland with those in/of the period of National Socialism, later, in west zones after 1945 and also in West Germany after 1949. Interesting graphic design and no less interesting topic engaged students' interest to look for other graphic novels, which naturally led to their interest in this part of history and to their voluntary search for other examples and information. During all these activities, their existing German language skills, thinking skills and evaluation of visual documentary material were practised. 


\section{Acknowledgments}

The contribution is financially supported by a grant of the Specific research 2021 of the Faculty of Education of the University of Hradec Kralove (No. 2121/1360/1210).

\section{References}

Apruzzese, J. P. (2019). The Universal Memoir: An Interview with Nora Krug. The NBCC autobiography award winner on Belonging: A German Reckons with History and Home. https://publicseminar.org/2019/05/the-universal-memoir-an-interview-with-nora-krug/

Besedova, P., \& Voriskova, V. (2020). Foreign Language Perception of University Teachers of Music and Foreign Languages. European Proceedings of International Conference on Education \& Educational Psychology, 1, 175-185. https://doi.org/10.15405/epiceepsy.20111.16

Crawford, P. (2004). A novel approach: Using graphic novels to attract reluctant readers and promote literacy. Library Media Connection, 22(5), 26-28.

Elsner, D. (2013). Graphic Novels in the Limelight of a Multiliteracies Approach to Teaching English. In D. Elsner, S. Helff, \& B. Viebrock (Eds.) Films, Graphic Novels \& Visuals: Developing Multiliteracies in Foreign Language Education - An Interdisciplinary Approach (pp. 55-71). LIT Verlag.

Gallo, D., \& Weiner, S. (2004). Bold books for innovative teaching: Show, don't tell: Graphic novels in the classroom. English Journal, 94(2), 114-117. https://doi.org/10.2307/4128785

Goodson, I., Knobel M., Lankshear C., \& Mangan, M. (Eds.) (2002). Cyber Space/Social Spaces. Culture Clash in Computerized Classrooms. Palgrave Macmillan. https://doi.org/10.1057/9780230602151

Griffith, P. E. (2010). Graphic Novels in the Secondary Classroom and School Libraries. Journal of Adolescent \& Adult Literacy, 54(3), 181-189. https://doi.org/10.1598/JAAL.54.3.3

Handschuh, G. (1990). Brauchtum: Zwischen Tradition und Veränderung. In Heimat. Analysen, Themen, Perspektiven (pp. 633-674). Bundeszentrale für politische Bildung.

Harmsen, R. C. (2012, May). Nicht $\mathrm{zu}$ stark wollen, dafür lange. Goethe Institut. https://www.goethe.de/ins/cz/prj/jug/the/com/de10740992.htm

Heinrichova, N. (2020). Generational novel in Times of Fading light by Eugen Ruge in FLT. European Proceedings of International Conference on Education \& Educational Psychology, 1, 72-79. https://doi.org/10.15405/epiceepsy.20111.7

McTaggart, J. (2008). Graphic Novels: The Good, the Bad, and the Ugly. In N. Frey, \& D. B. Fisher (Eds.), Teaching Visual Literacy: Using Comic Books, Graphic Novels, Anime, Cartoons, and More to Develop Comprehension and Thinking Skills (pp. 27-46). Corwin.

Mlsova, N. (2003). The theme of home life in Jaroslav Havlicek's prose fiction. Ceska Literatura, 51(4), 419-440.

Norton, B. (2003). The motivating power of comic books: Insights from Archie comic readers. The Reading Teacher, 57(2), 140-147.

Ondrakova, J., \& Tauchmanova, V. (2020). Comparison of the verbal category of tense in German and English. European Proceedings of International Conference on Education \& Educational Psychology, 1, 166-174. https://doi.org/10.15405/epiceepsy.20111.15

Oltermann, P. (2018). Nora Krug: I would have thought, what's left to say about Germany's Nazi past? The Guardian. https://www.theguardian.com/books/2018/oct/03/nora-krug-germany-nazi-pastheimat-memoir-author-illustrator

Piepgras, I. (2018). Heimat. Der Erinnerung auf der Spur [Homeland: On the trail of memories]. Die Zeit. https://www.zeit.de/zeit-magazin/2018/34/heimat-nationalsozialismus-tagebuch-illustration-norakrug 